IN MEMORIAM

\title{
Alasdair Cameron
}

2 March 1953-17 June 1994

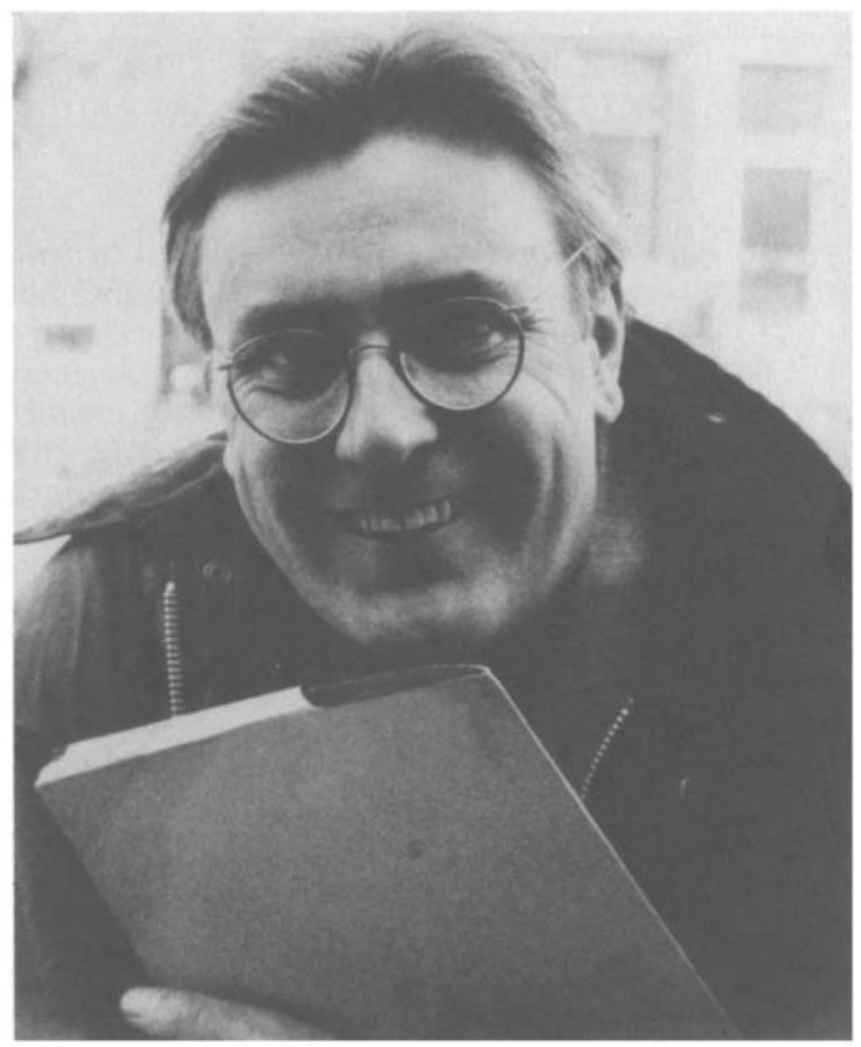

Alasdair has left us, but we shall always remember his smile, his sparkling eyes, his wit, his intelligence, his kindness. He lives on in our hearts.

je suis ce cours de sable qui glisse entre le galet et la dune la pluie d'été pleut sur ma vie sur moi ma vie qui me fuit me poursuit et finira le jour de son commencement

cher instant je te vois

dans ce rideau de brume qui recule où je n'aurai plus à fouler ces longs [seuils mouvants

et vivrai le temps d'une porte qui s'ouvre et se referme

(Beckett, 'Six Poèmes 1947-1949') my way is in the sand flowing between the shingle and the dune the summer rain rains on my life on me my life harrying fleeing to its beginning to its end

my peace is there in the receding mist when I may cease from treading these long [shifting thresholds and live the space of a door that opens and shuts 